\title{
Taxonomic Note: the Potential of Dead Bacterial Specimens for Systematic Studies
}

\author{
P. H. A. SNEATH \\ Department of Microbiology and Immunology, Leicester University, \\ Leicester, LE1 9HN, United Kingdom
}

\begin{abstract}
Consideration should be given to preserving nonliving bacterial specimens as dried material in herbaria for use in future systematic studies. Nucleic acid sequences can be recovered from such material, and it may be possible to utilize it in other techniques. Dried specimens are cheap to prepare and preserve and would record much bacterial variation without the expense of maintaining living cultures. They would also be useful for uncultivable microorganisms. Some technical suggestions are offered.
\end{abstract}

Bacteriology has relied very heavily on living cultures in culture collections, and much attention is paid to maintaining type cultures at considerable expense. In contrast, there is little interest in dead material, although the International Code of Nomenclature of Bacteria $(4,6,7)$ has always made provision for preserved materials to be the types of uncultivable bacteria. Recent discussions at the meeting of the International Committee on Systematic Bacteriology at the 7 th International Congress of Bacteriology and Applied Microbiology in Prague, Czech Republic, in July 1994 raised the question of whether much more use can now be made of dead preserved material. In this paper I suggest ways in which this could be achieved and discuss some technical problems that require study.

There has been a large increase in the number of described species of bacteria, from about 2,000 in 1980 to nearly 4,000 almost 10 years later $(9,13)$. Workers evidently have described only a small proportion of the species in nature. Many bacteria are not cultivable, although they are abundant in algal mats or in insect hosts. Organisms are being described from the environment on the basis of limited data, which is raising nomenclatural problems (10), yet our knowledge of bacterial variation indicates that satisfactory delimitation of species and identification of new isolates require descriptions based on a reasonable number of strains of each species (14). The withinspecies variation in bacteria seems to extend to nucleic acid sequences (2), although this subject has not been explored a great deal.

At the same time, the costs of maintaining living cultures, whether by freeze-drying or deep freezing, are a considerable burden on culture collections. Culture collections find it increasingly difficult to maintain strains other than the type strains of new species. Furthermore, specialized collections of microorganisms are at risk when the workers concerned retire, although the well-documented variation in such collections is a valuable resource.

Technical advances in molecular biology have greatly increased the potential of dead preserved material. Nucleic acid sequences, both DNA and RNA sequences, can be obtained from dried material by the PCR. Fungal mycelia and bacteria in desiccated arthropods can be used successfully $(1,12)$. No specialized preservation techniques are required. It is possible by using appropriate primers to amplify the sequences of particular toxins or enzymes that are significant for the study of within-species variation. It is possible that improvements in miniaturized techniques may lead to obtaining useful DNA pairing results from dried material. Such material can also be checked for identity with nucleic acid probes.

I suggest that experiments to determine the best methods for preserving dead bacteria should be performed. The simplest solution is to preserve dried material in herbaria. Botanical and mycological institutions, which have an international network of contacts (3), could offer facilities to microbiology departments in the same or nearby institutions. Fungal collections already combine facilities for preserving both dead and living material, together with excellent documentation experience. Culture collections of microorganisms could develop similar facilities and arrange deposition and exchange through the World Federation of Culture Collections (15). Descriptions of strains could also be recorded in the Microbial Strain Data Network (5). It would be worth considering depositing duplicate specimens, one in the originating institution and the other in a national collection.

One simple method would be to soak filter paper discs or strips with bacterial cultures or cell suspensions and let them dry. The discs or strips could then be attached to good-quality paper herbarium sheets and stored in box files or ring binders. The filter paper could be stored in small envelopes attached to the herbarium sheets, as is common with mosses, liverworts, and lichens. This would be convenient for algal mats and dried arthropods. Alternatively, the filter paper could be attached directly to sheets with adhesive; polyethylene-backed filter paper, such as Benchkote (Whatman Paper Ltd.), could be used for the sheets, and discs or strips of the same material could be attached with permanent sticky tape (e.g., Scotch Magic tape [3M Co.]). Even if they were wet, the discs or strips would dry out laterally in a day or two. Many specimens could be preserved on a single herbarium sheet, with details concerning them recorded in pencil or Indian ink (both of which have great permanency). Complete sterility would not be important, and most cultures are sufficiently gummy to prevent the material from spreading as dust. Care should be taken to avoid touching the material unnecessarily because there are nucleic acids or nucleases in sweat and sebum.

There would be no need to sterilize cultures of nonpathogens, although it might be best to sterilize all cultures in order to prevent damage to nucleic acids from autolysis. Steaming or autoclaving would be appropriate. If chemical disinfection was required, this would be best achieved by polar solvents, such as ethanol or dilute phenol. After long periods of time these compounds would also kill endospores. Both ethanol and dilute phenol are widely used in the purification of nucleic acids and therefore probably would not damage them. Formaldehyde or ethylene oxide would best be avoided because of the ability of these compounds to cross-link molecules (although nucleic acid sequences can be recovered from material treated with formaldehyde [11]). Thymol (commonly used to 
prevent growth of molds) and methyl bromide (used to protect herbarium material from arthropod pests) would probably be innocuous. Many agents persist in trace amounts for long periods of time, so study of chemical disinfection may be worthwhile. It seems unlikely that it would be necessary to store herbarium sheets under extremely dry conditions (e.g., in sealed tins with desiccant), but a study of this is desirable.

There would be advantages in handling specimens with stout nichrome wire instruments, because such instruments can be decontaminated by heating them to redness. Forceps are easily contaminated and difficult to clean thoroughly. Material would best be recovered with nichrome wire or clean scalpel blades. Paper and adhesives should be checked for the presence of nucleic acids. Although sterility is not essential, it is important to reduce external contamination to a minimum because PCR amplification of foreign DNA can lead to much confusion.

The use of dried material is not restricted to nucleic acids. It has always been possible to use dead bacteria for serology, although I am not aware of attempts to produce antibodies from dried material or to use dried material as an antigen for antigen-antibody reactions. In some newer chemical analysis techniques (8) very small amounts of bacterial cells can be used, and there should be further advances in such use.

I am grateful to V. Norris, R. G. E. Murray, and R. Castenholz for helpful comments.

\section{REFERENCES}

1. Bowman, B. H. 1993. A model PCR/probe system for the identification of fungal pathogens, p. 423-430. In D. H. Persing, T. F. Smith, F. C. Tenover, and T. J. White (ed.), Diagnostic molecular microbiology. Principles and applications. American Society for Microbiology, Washington, D.C.

2. Fox, G. H., J. D. Wisotzkey, and P. Jurtshak, Jr. 1992. How close is close: $16 \mathrm{~S}$ rRNA sequence identity may not be sufficient to guarantee species identity. Int. J. Syst. Bacteriol. 42:166-170.
3. Holmgren, P. K., W. Keuken, and E. K. Schofield. 1981. Index herbariorum, part I. The herbaria of the world, 7th ed. Bohn, Scheltema \& Holkema, Utrecht, The Netherlands.

4. Iowa State College Press. 1958. International code of nomenclature of bacteria and viruses. Iowa State College Press, Ames.

5. Kirsop, B. E. 1988. Microbial strain data network: a service to biotechnology. Int. Ind. Biotechnol. 8:224-227.

6. Lapage, S. P., P. H. A. Sneath, E. F. Lessel, V. B. D. Skerman, H. P. R. Seeliger, and W. A. Clark (ed.). 1975. International code of nomenclature of bacteria. 1976 Revision. American Society for Microbiology, Washington, D.C.

7. Lapage, S. P., P. H. A. Sneath, E. F. Lessel, V. B. D. Skerman, H. P. R. Seeliger, and W. A. Clark (ed.). 1992. International code of nomenclature of bacteria: bacteriological code. 1990 Revision. American Society for Microbiology, Washington, D.C.

8. Magee, J. T. 1994. Analytical fingerprinting methods, p. 523-553. In M. Goodfellow and A. G. O'Donnell (ed.), Chemical methods in prokaryotic systematics. John Wiley, New York.

9. Moore, W. E. C., and L. V. H. Moore. 1989. Index of the bacterial and yeast nomenclatural changes published in the International Journal of Systematic Bacteriology since the 1980 Approved Lists of Bacterial Names. American Society for Microbiology, Washington, D.C.

10. Murray, R. G. E., and K. H. Schleifer. 1994. Taxonomic notes: a proposal for recording the properties of putative taxa of prokaryotes. Int. J. Syst. Bacteriol. 44:174-176.

11. Relman, D. A. 1993. Universal bacterial 16S rDNA amplification and sequencing, p. 489-495. In D. H. Persing, T. F. Smith, F. C. Tenover, and T. J. White (ed.), Diagnostic molecular microbiology. Principles and applications. American Society for Microbiology, Washington, D.C.

12. Rys, P. N. 1993. PCR detection of Borrelia burgdorferi, p. 203-210. In D. H. Persing, T. F. Smith, F. C. Tenover, and T. J. White (ed.), Diagnostic molecular microbiology. Principles and applications. American Society for Microbiology, Washington, D.C.

13. Skerman, V. B. D., V. MeGowan, and P. H. A. Sneath (ed.). 1980. Approved lists of bacterial names. Int. J. Syst. Bacteriol. 30:225-420.

14. Sneath, P. H. A. 1977. The maintenance of large numbers of strains of microorganisms, and the implications for culture collections. FEMS Microbiol. Lett. 1:333-334.

15. Staines, J. E., V. F. McGowan, and V. B. D. Skerman. 1986. World directory of collections of cultures of microorganisms, 3rd ed. World Data Centre, St. Lucia, Australia. 